ACTA UNIVERSITATIS LODZIENSIS

FOLIA LITTERARIA POLONICA 5(43) 2017

http://dx.doi.org/10.18778/1505-9057.43.05

Paulina Czarnek-Wnuk*

\title{
Hybrid forms of entertainment in the media
}

\section{Introduction}

"Humanities is a contractual discoursive space, which can be, just like any discoursive space, changed whenever it is proved that the tools which we use to achieve specific goals are ineffective"1, stated Michał Paweł Markowski when analysing the location of human reflection as a social being in contemporary research consideration. That claim, which actually referred to a slightly different issue, inspired me to focus on the media as a discoursive space where there occur various modifications which constitute a reaction to the changing reality. The flux of post-modernity, the constant transcending of new borders, the blurring of genre limitations ${ }^{2}$, hybridisation, and various other phenomena associated with technological progress are the reasons why the research field, including in terms of the media, is being filled with ever newer points of reference. In this study, I focus on the various entertainment phenomena which one can observe in the contemporary media space, and which assume the nature of mixed forms combining various functions. The goal of this study was to indicate the hybrid entertainment forms appearing most often in the mass media, to define their nature, and the roles they fulfil. I attempt to show whether those types of media structure are productive, and how they influence the phenomena which constitute their components.

* Ph.D., e-mail: paulina-czarnek@wp.pl; Chair of Journalism and Social Communication, Faculty of Philology, University of Lodz.

${ }^{1}$ M.P. Markowski, "Polityka wrażliwości. Wprowadzenie do humanistyki”, Towarzystwo Autorów i Wydawców Prac Naukowych Universitas, Cracow 2013, p. 70.

${ }^{2}$ M. Duszak, "Centra, hybrydy i zmiana społeczno-dyskursywna", Oblicza Komunikacji 2012, Issue 5, pp. 18-20. 


\section{Entertainment - a media imperative}

The media, particularly the commercial media, are consumed in a way similar to any other market product. Thus, it is very important to make the message attractive enough for it to be able to draw the attention of an extensive group of receivers. One of the most frequently used incentives, apart from sensationalism ${ }^{3}$, is entertainment, which can assume various forms. The need to come into contact with amusement, to participate in it in the contemporary world, not only of the media, is deeply rooted, an issue which was raised by Jean Baudrillard in Spoteczeństwo konsumpcyjne (The Consumer Society). He indicated the so-called fun morality, i.e. the entertainment imperative ${ }^{4}$, reflected in the form of a continuous desire to ensure oneself pleasure. That imperative seems to be maintained also by the media which constantly feed their receivers with various forms of entertainment cementing their conviction that the quality of being ludic is an important element of everyday life.

Several decades ago, such researchers as Marshall McLuhan and Neil Postman tried to present the destructive influence of such an approach to the media and their audience. The former, in a text of 1964, noted that "the commercial entertainment strategy automatically ensures maximum speed and force of impact for any medium, on psychic and social life equally. It thus becomes a comic strategy of unwitting self-liquidation, conducted by those who are dedicated to permanence, rather than to change"s.

Entertainment can quite quickly and easily bring both the sender and the receiver the expected temporary benefits (of course different for each of the groups) at the same time leading to long-term negative results. Postman considered entertainment as a supra-ideology of media discourse ${ }^{6}$, which permeates various primarily non-entertainment areas, e.g. the news, thus making the content something in the shape of a vaudeville act ${ }^{7}$, devoid of any value, and aimed at satisfy-

\footnotetext{
${ }^{3}$ Pleasure drawn from entertainment can have ambivalent interpretations, which is why a sensationalistic nature or the dread accompanying the watching of horror films are also sometimes its source.

${ }^{4}$ J. Baudrillard, "Społeczeństwo konsumpcyjne. Jego mity i struktury”, transl. by S. Królak, Wydawnictwo Sic!, Warsaw 2006, p. 93.

${ }^{5}$ M. McLuhan, "Radio. Plemienny bęben”, in: ibid., "Zrozumieć media. Przedłużenia człowieka”, transl. by N. Szczucka, Wydawnictwa Naukowo-Techniczne, Warsaw 2004, p. 393 (English version: https://is.vsfs.cz/el/6410/zima2016/BA_MD/5269324/McLuhan258-307.txt [accessed on: 10.06.2017]).

${ }^{6}$ N. Postman, “Zabawić się na śmierć. Dyskurs publiczny w epoce show-businessu”, transl. by L. Niedzielski, Wydawnictwo Muza, Warsaw 2002, p. 130 [translated into English from Polish].

${ }^{7}$ Ibid., p. 220 [English version: N. Postman, "Amusing Ourselves to Death: Public Discourse in the Age of Show Business", Penguin Group, New York 1986].
} 
ing primary needs. As Magdalena Sternicka has noted, the influence of entertainment on other forms of communication is extremely high:

The borderline between what is and what is not entertainment is becoming increasingly blurry. Entertainment is elbowing its way through, it is everywhere. [...] The way the contemporary media operate consists of a "tyranny of the majority", where the tyrant is the viewer and the viewership she/he builds. Thus, everything must be surprising, exciting, it must be attractive for the increasingly bored receivers who constantly seek new stimuli and experiences ${ }^{8}$.

That "elbowing" and blending with various forms of media content by entertainment results in the creation of new variants of amusement which I shall raise later in this discussion. However, entertainment is not always assigned only negative attributes. It can, in fact, help us unwind, relax, reduce stress and tension, and enable a person to test her/his skills in competition-based forms of entertainment.

\section{Hybrid blends}

The phenomenon of hybridisation is often associated with contemporary genres, both media-based, as well as literary or film. It is also used for discussing linguistic phenomena and more. The forms created through the process of blending significantly alter the genological landscape transcending genre borders, changing the distinctive features of specific genres, and forcing a redefinition of a number of notions. In relation to the media, some of the most productive seem to be the various types of combinations which form based on entertainment which encompasses the genres and phenomena primarily used for completely different goals? . Amusement in its pure form mediated by the media appears, e.g. in talent shows or reality show productions. However, as well as those, viewers have at their disposal an entire array of entertainment hybrids, where the ludic function is blended with the informative, educational, impressive, phatic, opinion-making or other functions.

\footnotetext{
${ }^{8}$ M. Sternicka, "Cyberprzestrzeń jako dostawca rozrywki oraz miejsce autokreacji - na przykładzie serwisu internetowego YouTube”, in: “"Małe tęsknoty?’ Style życia w czasie wolnym we współczesnym społeczeństwie”, W. Muszyński (ed.), Wydawnictwo Adam Marszałek, Toruń 2009 , p. 85.

${ }^{9}$ The act of combining the entertainment and non-entertainment functions was discussed by: S. Bates, A.J. Ferri, "What's Entertainment? Notes Toward Definition", Studies in Popular Culture 2010, Issue 33.1, p. 2.
} 
However, before I discuss the most common instances of entertainment blends appearing both in academic research and in media practice, I shall briefly refer to the understanding of the notion of a hybrid.

The dictionary definition of a hybrid indicates two main meanings of the term, one of which can be applied to the humanities (the other is appropriate for natural sciences). The notion that interests me is considered in it as "a combination of various elements, often unfit for each other" ${ }^{\prime 1}$, and as an example of a hybrid the dictionary indicates a work non-homogeneous in terms of its genre. The authors of Stownik jezzyka polskiego added that in that approach, the notion is sometimes assigned a negative interpretation. Its non-homogeneity stems from the primary meaning of the word hybrid, as indicated in Stownik wyrazów obcych, which was derived from the Latin word hybrida meaning a child of a Roman man and a nonRoman woman ${ }^{11}$.

The notion can also be considered based on its literary interpretation. A textual hybrid was defined by Grzegorz Grochowski, who considered it a combination within a single text of the typical literary approaches with scientific or journalistic approaches, which results in a "destabilisation of the discoursive status of an utterance"12. The distinctive features of a textual hybrid include the multifunctional nature of an utterance, and the diversity of the levels of reference ${ }^{13}$. And that does not only apply to intertextual relationships, but rather to a deeper relationship between texts of various types.

Media researchers also study the phenomenon of hybridisation in various contexts. Agnieszka Ogonowska in Stownik wiedzy o mediach associated it with the act of merging of the features of various genres within a single television show ${ }^{14}$. Janina Fras used the term "hybrid utterance" which she understood as "an utterance combining two (or more) genres with completely different definitional characteristics (markers), particularly different functions"15. She also referred to the phenomenon of infotainment, which, according to her, constitutes a tendency in the development of the mass media towards a hybridisation of utterances ${ }^{16}$.

10 "Hybryda", in: "Słownik języka polskiego", M. Bańko (ed.), $2^{\text {nd }}$ edition, Wydawnictwo Naukowe PWN, Warsaw 2007, p. 106.

11 "Hybryda", in: “Słownik wyrazów obcych", L. Wiśniakowska (ed.), Wydawnictwo Naukowe PWN, Warsaw 2007, p. 154.

${ }^{12}$ G. Grochowski, "Tekstowe hybrydy. Literackość i jej pogranicza”, Wydawnictwo Funna, Wroclaw 2000, p. 17.

${ }^{13}$ Ibid.

${ }^{14}$ A. Ogonowska, "Gatunki telewizyjne", in: "Słownik wiedzy o mediach", E. Chudziński (ed.), Wydawnictwo Szkolne PWN, Warsaw-Bielsko-Biała 2009, p. 319.

${ }^{15}$ J. Fras, "Podstawy identyfikacji typologii wypowiedzi w mediach masowych", in: "Komunikologia. Teoria i praktyka komunikacji”, E. Kulczycki, M. Wendland (eds.), Wydawnictwo Naukowe IF UAM, Poznan 2012, p. 22.

${ }^{16}$ Ibid. 
In media studies, the process of hybridisation is sometimes considered as a method of increasing the attractiveness of content by combining various elements of different genre patterns and styles ${ }^{17}$, which leads to the formation of fringe and syncretic forms which constitute a blend of features that are not always homogeneous. Thus, there occurs a special kind of colonisation by entertainment of other types and forms of content (I understand the said colonisation similarly to how it is considered in natural sciences: as entertainment's settlement of an area where it previous did not exist). That is the case due to the fact that the media strive to use amusement to sell content which is not primarily ludic, probably based on the assumption that a packaging of entertainment makes the content more interesting for the receivers. Moreover, broadcasters pretend to care about the pluralism of the issues they raise by combining amusement with social or political issues, but, in my opinion, it is largely limited, and I would even venture a conclusion that the permeation of entertainment into various media areas increases content homogenisation.

The act of utilising such programming mixtures may also prove detrimental to genre purity.

In order for the act of communication to be considered significant [...], it is necessary to respect genre conventions. By negating them we may easily be led to a special type of hybridisation or syncretism, which will only legitimise the mixing of fact and fiction, knowledge and emotions, and information and entertainment ${ }^{18}$

wrote Elżbieta Pleszkun-Olejniczakowa. In fact, on the one hand, hybrid forms may lead to the exploitation of new meanings and a refreshing of well-worn patterns, while, on the other, it might, in fact, lead to genre "anarchy".

The spike in the number of instances of mixed forms is sometimes related to the development of new media where, as Jacek Dąbała has noted, amateur-media users rather than journalists utilise journalistic genres quite freely and without any deeper consideration of their markers, thus causing the creation of hybrids.

The ability to express oneself in any way at any time without any control, criticism or even editing of the content, the ability to reply to virtual pestering, suggestions, and requests in new media to become vocal and express one's opinion have led to a boom in journalistic and fringe genres, and to the rise of a mixture of styles $[\ldots]^{19}$.

${ }^{17}$ A. Hanus, "Wariantywność gatunkowa w ujęciach kontrastywnych na przykładzie wybranych polskich i niemieckich tabloidów", Tekst i Dyskurs - Text und Diskurs 2014, Issue 7, p. 203.

18 E. Pleszkun-Olejniczakowa, "Media nasze powszednie", in: "Poznawanie słowa", P. Stalmaszczyk (ed.), Wydawnictwo Primum Verbum, Lodz 2010, p. 34.

19 J. Dąbała, "Media i dziennikarstwo. Aksjologia - warsztat - tożsamość", Towarzystwo Autorów i Wydawców Prac Naukowych Universitas, Cracow 2014, p. 15. 
And even though genre and style blends did, of course, exist before the development of the digital community, the convergence phenomenon has certainly led to an intensification of the process of their creation.

Therefore, let us see what hybrid forms of entertainment have emerged in the media discourse. Initially, researchers mainly wrote about probably the most popular phenomenon, i.e. infotainment, which is a mixture of news and entertainment ${ }^{20}$, and the phenomenon of edutainment, which, to some extent, constitutes a contemporary version of the Enlightenment maxim of "teach and play, play and learn" 21 . Today, the range of such hybrid terms is, in fact, constantly expanding. Some of those revolve around politics and the notion of a democratic society. Some refer to democratainment, i.e. presentation in social media of the issues related to democracy as a spectacle or amusement ${ }^{22}$ (at the same time, it is strongly emphasised in media entertainment that the means of mass communication are open to their receivers and they can use them as they please), politainment - entertainment packaging of politics ${ }^{23}$ (e.g. intentional political activity performed through an entertainment channel), there also exists politicotainment, which is defined as the existence of political themes in entertainment shows ${ }^{24}$ (e.g. the use of political issues in television series), as well as the civil society-related notion of charitainment, which combines charity work with entertainment ${ }^{25}$ (e.g. the mode

${ }^{20}$ Infotainment was discussed by, e.g. J. Fras, "O pojmowaniu infotainmentu i nadmiernej rozrywkowości mediów masowych we współczesnym medioznawstwie", Środkowoeuropejskie Studia Polityczne 2013, Issue 1, pp. 7-32; W. Godzic, “Telewizja i jej gatunki. Po 'Wielkim Bracie”, Towarzystwo Autorów i Wydawców Prac Naukowych Universitas, Cracow 2004, pp. 64-92; T. Jagodziński, "Przekleństwo info-rozrywki”, Znak 2002, Issue 2, pp. 5-12; K. Krzysztofek, "Infotainment. Dziennikarstwo w świecie przemysłów informacyjnych", in: "Media i dziennikarstwo na przełomie wieków", J. Adamowski (ed.), Wydawnictwo Instytutu Dziennikarstwa Uniwersytetu Warszawskiego, Warsaw 1998, pp. 116-125; P. Legutko, D. Rodziewicz, "Gra w media. Między informacją a dezinformacją", Wydawnictwo Stentor, Warsaw 2007; M. Lisowska-Magdziarz, "Media powszednie. Środki komunikowania masowego i szerokie paradygmaty medialne w życiu codziennym Polaków u progu XXI wieku”, Wydawnictwo Uniwersytetu Jagiellońskiego, Cracow 2008, pp. 147-190.

${ }^{21}$ Edutainment was discussed by, e.g. M. Piechota, "Strategie edutainment a sytuacja komunikacyjna", in: "Nowe zjawiska w języku, tekście i komunikacji III. Kontekst a komunikacja", I. Matusiak-Kempa, S. Przybyszewski (ed.), Centrum Badań Europy Wschodniej Uniwersytetu Warmińsko-Mazurskiego w Olsztynie, Olsztyn 2011, pp. 352-361.

${ }^{22}$ M. Lisowska-Magdziarz, op. cit., p. 238.

${ }^{23}$ Vide: E. Nowak, "Komercjalizacja komunikacji politycznej - infotainment i politainment w programach informacyjnych", Annales Universitatis Mariae Curie-Skłodowska. Sectio K 2009, Vol. 16.2, pp. 201-213; M. Szatan, "Politainment, czyli jak media przekształcają politykę w spektakl (na przykładzie kampanii wyborczej 2011)", in: "Rozrywka w mediach", K. Burska, P. Czarnek (eds.), Wydawnictwo Primum Verbum, Lodz 2012, pp. 201-211.

${ }^{24}$ D. Piontek, O. Annusiewicz, "Polityka popularna: celebrytyzacja polityki, politainment, tabliodyzacja", e-Politikon 2013, Issue 5, pp. 6-28.

${ }^{25}$ G. Stachyra, "Radio Charitainment. A Case Study of Radio Eska's Campaign 'We Undress to Dress", in: "Radio: Community, Challanges, Aesthetics", ibid. (ed.), Wydawnictwo Uniwersytetu Marii Curie-Skłodowskiej, Lublin 2013, pp. 287-297. 
of media presence of the Wielka Orkiestra Świątecznej Pomocy charity in Poland). Political issues, though not exclusively, can be presented using the formula of confrontainment ${ }^{26}$, which is related to the media rivalry present in political debates or talk shows, which are intentionally moderated so that the participants clash in the media arena, and deliver strong emotions ${ }^{27}$. Issues associated with documenting reality and presenting it in the media are also entertainment-profiled. That is increasingly done under the influence of docutainment ${ }^{28}$ in productions based on historical material, which is, however, used for ludic purposes (also in programmes of the documentary soap opera type) or socialtainment $t^{29}$ present in programmes depicting social issues in an "attractive" emotional way (e.g. in reportage shows); sometimes there appears shocktainment, i.e. the use of shocking matters for entertainment purposes. The media also include entertainment-based guidance ( guidetainment $^{30}$ ), advertising activities in the form of advertainment $t^{31}$, which, in essence, consists of convincing the consumers to purchase a product indirectly, disguised in amusing and intriguing content; there even exists erotainment (the notion is used to define the presentation in mainstream media of erotic themes right next to important or even grave issues) $)^{32}$. Finally, at the borderline between media and extra-media activities, there functions the notion of sacrotainment $t^{33}$, which refers to the use of entertainment for religious purposes (e.g. journalistic activities carried out in wide-reaching popular media raising religious issues associated with the spiritual life in a "light" manner accessible to the average receiver), and tanatainment $t^{34}$, which treats death as a distinct topic which

${ }^{26}$ H. Kriesi, S. Lavenex, F. Esser, J. Matthes, M. Bühlmann, D. Bochsler, "Democracy in the Age of Globalisation and Mediatization", Palgrave Macmillan, Basingstoke, Hampshire 2013, pp. 172-173.

${ }^{27}$ Agon based on rivalry and competition is one of the basic forms of games in Roger Caillois' typology (R. Caillois, “Żywioł i ład”, transl. by A. Tatarkiewicz, Państwowy Instytut Wydawniczy, Warsaw 1973, pp. 328-339). The confrontational nature of amusement was also discussed by Johan Huizinga (J. Huizinga, "Homo ludens. Zabawa jako źródło kultury”, transl. by M. Kurecka, W. Wirpsza, Wydawnictwo Czytelnik, Warsaw 1998, pp. 85-97).

${ }^{28}$ W. Godzic, op. cit., pp. 158-235.

${ }^{29}$ M. Bogunia-Borowska, "Telewizyjny entertainment - analiza procesu komercjalizacji telewizyjnej oferty programowej na przykładzie polskich stacji telewizyjnych", in: "Stawanie się społeczeństwa. Szkice oferowane Piotrowi Sztompce z okazji 40-lecia pracy naukowej”, A. Flis (ed.), Towarzystwo Autorów i Wydawców Prac Naukowych Universitas, Cracow 2006, p. 308.

${ }^{30}$ O. Dąbrowska-Cendrowska, "Guidetainment w polskich mediach - analiza zjawiska na wybranych przykładach”, Media i Społeczeństwo 2015, Issue 5, pp. 35-53.

${ }^{31}$ M. Lisowska-Magdziarz, "Feniksy, łabędzie, motyle. Media i kultura transparencji”, Wydawnictwo Uniwersytetu Jagiellońskiego, Cracow 2012, pp. 149-151.

32 A. Adamski, "Media w analogowym i cyfrowym świecie. Wpływ cyfrowej rewolucji na rekonfigurację komunikacji społecznej”, Dom Wydawniczy Elipsa, Warsaw 2012, pp. 190-191.

${ }^{33}$ J. Klimek, M. Nowak, "Język nowej (?) publicystyki religijnej”, in: “Język nowych mediów”, K. Michalewski (ed.), Wydawnictwo Primum Verbum, Lodz 2012, pp. 302-317.

${ }^{34}$ G. Gorer, "Pornografia śmierci", Teksty: teoria literatury, krytyka, interpretacja 1979, Issue 3 (45), pp. 197-203. 
offers receivers powerful emotions (e.g. in news programmes, on front pages of newspapers; the inclination to excessive use of death is particularly visible in tabloid or gossip media, which largely draw their popularity from it, often communicating completely unverified pieces of information regarding the deaths of famous people, which they use to draw attention).

Researchers also discuss blend structures based on entertainment in relation to the consumer society indicating, e.g. eatertainment, which is a combination of entertainment and eating (in fast food restaurants customers can not only eat something, but other pleasures: prizes, competitions, etc. also await them); retailtainment (evoking the urge to purchase items by utilising entertainmentbased devices, e.g. events which feature celebrities and are held in shopping malls - the so-called celebrity endorsement) ${ }^{35}$, or culturetainment, which is present, in the form of combining commercial and cultural activities (which can also be observed in the media).

Therefore, based on the above examples, one can conclude that there exists a large variety of entertainment blends, while their character is considerably diverse. Each one opens an extensive field for researchers. The goal of this study was not to offer a detailed analysis of each of them, which is why I limited it to only a short overview of those entertainment hybrids. While defining them, I did not use the term "form" as I do not consider such creations like edutainment or charitainment as genre hybrids, rather a special type of stylistic variants diverse in terms of their functions.

\section{Conclusion}

The multitude of hybrid forms based on entertainment which appear in discourse indicates the high productivity of that type of combination, and the strong position of entertainment itself, which permeates various areas. Therefore, the potentiality ${ }^{36}$ of such constructs seems high, and it is possible that in the future we will see new entertainment hybrids emerging in media practice. That tendency seems to have been confirmed by the transformations which can be observed in the new media, and which Lev Manovich considered in the form of the variation principle, which is based on blending various characteristics of new

\footnotetext{
${ }^{35}$ G. Ritzer, "Magiczny świat konsumpcji”, transl. by L. Stawowy, Warszawskie Wydawnictwo Literackie Muza, Warsaw 2001, pp. 41, 191.

${ }^{36}$ According to J. Baudrillard, "potentiality" is that which is actually being consumed by the receivers of mass media. It is not about what the media offer directly, but what is indirectly concealed underneath the content (J. Baudrillard, op. cit., p. 160).
} 
media which appear unrelated ${ }^{37}$. Following that argumentation, and applying it also to traditional media, one could conclude that such blends are and will be a type of media generality, a practice used for exploiting new meanings, and introducing a new level of quality to the means of mass communication.

In the case of hybrid forms, there exists a special type of relationality manifested in the fact that phenomena or notions with established significance acquire new meanings in the situation of blending with phenomena or notions which primarily represent completely different areas. Thus a piece of information combined with entertainment in a series of phenomena included in the infotainment category becomes modified, similarly to, in fact, the entertainment which cooperates with it. That relationality does not only consist of changing the meaning or the stylistic tint in a specific context. It constitutes an extensive transformation which results in the creation of a new variant-based form, while its distinctive features constitute a blend of the features of the phenomena constituting the relational mixture. It forms through a special type of a dialogue of sometimes quite distant interlocutors, e.g. education and entertainment, the paths of which intertwine, and lead to a common communication point or goal. Therefore, one could conclude that as a result of the merger, there form special types of media "alloys" or amalgams, which open a whole range of discoursive opportunities for both the senders and the receivers.

The relationship results not only in the creation of new communicational hybrid forms, but also in some transformation of their foundations, i.e. information and entertainment in the case of infotainment. One could venture even further. If one were to assume, following Baudrillard's argumentation, that in contemporary society special models are created based on blending various elements or features of reality in the media and, as a result, a kind of "neo-reality" 38 forms, and one was to transfer that notion onto the realm of hybrid entertainment forms, one could conclude that thanks to those blends we acquire new varieties of their components, i.e. neo-entertainment, neo-education, or neo-information. That could result in the emergence of special desires in the receivers of media content, who would expect pieces of information also in extra-media reality to possess an attractive sensational-emotional nature, or education to offer, apart from knowledge, a considerable portion of pleasure as well.

According to a statement from as early as the $19^{\text {th }} \mathrm{c.:}$ " [[...] many languages exist, between which there can exist various transitions and references" ${ }^{39}$. The conviction about a special kind of unity in diversity expressed in reference to the communication universe by Romantic writers can, I believe, be assigned

${ }^{37}$ L. Manovich, "Język nowych mediów”, transl. by P. Cypryański, Wydawnictwa Akademickie i Profesjonalne, Warsaw 2006, p. 107.

38 J. Baudrillard, op. cit., p. 165.

${ }^{39}$ M.P. Markowski, op. cit., p. 319. 
to the changes and the transcending of borders which we observe in contemporary mass communication. Stylistic conventions transcend each other, we can observe a variety of transitions and references, the media fill genological conglomerates, sets of genre-building forms and mega-genre hybrids ${ }^{40}$. Hybridisation is a multifaceted process, still ongoing, because, from my point of view, the distinctive feature of a hybrid is the fact that it undergoes a constant redefining, it forms and transforms: it is imbalanced. Moreover, due to the discoursive nature of the media, the above-mentioned dialogue between various forms of content is ongoing, and it continues to enter new areas.

\section{Bibliography}

Adamski A., "Media w analogowym i cyfrowym świecie. Wpływ cyfrowej rewolucji na rekonfigurację komunikacji społecznej”, Dom Wydawniczy Elipsa, Warsaw 2012.

Albińska K., "Poranna audycja radiowa jako hybryda megagatunkowa", Wydawnictwo Adam Marszałek, Torun 2017.

Bates S., Ferri A.J., "What's Entertainment? Notes Toward Definition”, Studies in Popular Culture 2010, Issue 33.1, p. 1-20.

Baudrillard J., "Społeczeństwo konsumpcyjne. Jego mity i struktury", transl. by S. Królak, Wydawnictwo Sic!, Warsaw 2006.

Bogunia-Borowska M., “Telewizyjny entertainment - analiza procesu komercjalizacji telewizyjnej oferty programowej na przykładzie polskich stacji telewizyjnych", in: "Stawanie się społeczeństwa. Szkice oferowane Piotrowi Sztompce z okazji 40-lecia pracy naukowej”, A. Flis (ed.), Towarzystwo Autorów i Wydawców Prac Naukowych Universitas, Cracow 2006, p. 293-318.

Caillois R., "Żywioł i ład”, transl. by A. Tatarkiewicz, Państwowy Instytut Wydawniczy, Warsaw 1973.

Dąbała J., "Media i dziennikarstwo. Aksjologia - warsztat - tożsamość", Towarzystwo Autorów i Wydawców Prac Naukowych Universitas, Cracow 2014.

Dąbrowska-Cendrowska O., "Guidetainment w polskich mediach - analiza zjawiska na wybranych przykładach”, Media i Społeczeństwo 2015, Issue 5, pp. 35-53.

Duszak M., "Centra, hybrydy i zmiana społeczno-dyskursywna”, Oblicza Komunikacji 2012, Issue 5, pp. 18-20.

Fras J., "O pojmowaniu infotainmentu i nadmiernej rozrywkowości mediów masowych we współczesnym medioznawstwie”, Środkowoeuropejskie Studia Polityczne 2013, Issue 1, pp. 7-32.

Fras J., "Podstawy identyfikacji typologii wypowiedzi w mediach masowych", in: "Komunikologia. Teoria i praktyka komunikacji”, E. Kulczycki, M. Wendland (eds.), Wydawnictwo Naukowe IF UAM, Poznan 2012, pp. 13-29.

Godzic W., “Telewizja i jej gatunki. Po 'Wielkim Bracie”, Towarzystwo Autorów i Wydawców Prac Naukowych Universitas, Cracow 2004.

Gorer G., "Pornografia śmierci”, Teksty: teoria literatury, krytyka, interpretacja 1979, Issue 3 (45), pp. 197-203.

40 The notion in relation to the radio was analysed by: K. Albińska, "Poranna audycja radiowa jako hybryda megagatunkowa”, Wydawnictwo Adam Marszałek, Torun 2017. 
Grochowski G., “Tekstowe hybrydy. Literackość i jej pogranicza”, Wydawnictwo Funna, Wroclaw 2000. Hanus A., "Wariantywność gatunkowa w ujęciach kontrastywnych na przykładzie wybranych polskich i niemieckich tabloidów", Tekst i Dyskurs - Text und Diskurs 2014, Issue 7, p. 197-218.

Huizinga J., "Homo ludens. Zabawa jako źródło kultury", transl. by M. Kurecka, W. Wirpsza, Wydawnictwo Czytelnik, Warsaw 1998.

"Hybryda", in: "Słownik języka polskiego", M. Bańko (ed.), 2 nd edition, Wydawnictwo Naukowe PWN, Warsaw 2007, p. 106.

"Hybryda", in: "Słownik wyrazów obcych", L. Wiśniakowska (ed.), Wydawnictwo Naukowe PWN, Warsaw 2007, p. 154.

Jagodziński T., "Przekleństwo info-rozrywki”, Znak 2002, Issue 2, pp. 5-12.

Klimek J., Nowak M., “Język nowej (?) publicystyki religijnej”, in: "Język nowych mediów”, K. Michalewski (ed.), Wydawnictwo Primum Verbum, Lodz 2012, pp. 302-317.

Kriesi H., Lavenex S., Esser F., Matthes J., Bühlmann M., Bochsler D., "Democracy in the Age of Globalisation and Mediatization”, Palgrave Macmillan, Basingstoke, Hampshire 2013.

Krzysztofek K., "Infotainment. Dziennikarstwo w świecie przemysłów informacyjnych”, in: "Media i dziennikarstwo na przełomie wieków”, J. Adamowski (ed.), Wydawnictwo Instytutu Dziennikarstwa Uniwersytetu Warszawskiego, Warsaw 1998, pp. 116-125.

Legutko P., Rodziewicz D., "Gra w media. Między informacją a dezinformacją”, Wydawnictwo Stentor, Warsaw 2007.

Lisowska-Magdziarz M., "Feniksy, łabędzie, motyle. Media i kultura transparencji”, Wydawnictwo Uniwersytetu Jagiellońskiego, Cracow 2012, pp. 149-151.

Lisowska-Magdziarz M., "Media powszednie. Środki komunikowania masowego i szerokie paradygmaty medialne w życiu codziennym Polaków u progu XXI wieku”, Wydawnictwo Uniwersytetu Jagiellońskiego, Cracow 2008, pp. 147-190.

Manovich L., "Język nowych mediów”, transl. by P. Cypryański, Wydawnictwa Akademickie i Profesjonalne, Warsaw 2006.

Markowski M.P., "Polityka wrażliwości. Wprowadzenie do humanistyki”, Towarzystwo Autorów i Wydawców Prac Naukowych Universitas, Cracow 2013.

McLuhan M., "Radio. Plemienny bęben”, in: ibid., "Zrozumieć media. Przedłużenia człowieka", transl. by N. Szczucka, Wydawnictwa Naukowo-Techniczne, Warsaw 2004 (English version: https://is.vsfs.cz/el/6410/zima2016/BA_MD/5269324/McLuhan258-307.txt [accessed on: 10.06.2017]).

Nowak E., "Komercjalizacja komunikacji politycznej - infotainment i politainment w programach informacyjnych", Annales Universitatis Mariae Curie-Skłodowska. Sectio K 2009, Vol. 16.2, pp. 201-213.

Ogonowska A., "Gatunki telewizyjne”, in: "Słownik wiedzy o mediach", E. Chudziński (ed.), Wydawnictwo Szkolne PWN, Warsaw-Bielsko-Biała 2009, pp. 313-326.

Piechota M., "Strategie edutainment a sytuacja komunikacyjna", in: "Nowe zjawiska w języku, tekście i komunikacji III. Kontekst a komunikacja”, I. Matusiak-Kempa, S. Przybyszewski (ed.), Centrum Badań Europy Wschodniej Uniwersytetu Warmińsko-Mazurskiego w Olsztynie, Olsztyn 2011, pp. 352-361.

Piontek D., Annusiewicz O., "Polityka popularna: celebrytyzacja polityki, politainment, tabliodyzacja", e-Politikon 2013, Issue 5, pp. 6-28.

Pleszkun-Olejniczakowa E., "Media nasze powszednie”, in: "Poznawanie słowa”, P. Stalmaszczyk (ed.), Wydawnictwo Primum Verbum, Lodz 2010, pp. 24-60. 
Postman N., "Zabawić się na śmierć. Dyskurs publiczny w epoce show-businessu”, transl. by L. Niedzielski, Wydawnictwo Muza, Warsaw 2002 [English version translated from Polish].

Postman N., "Amusing Ourselves to Death: Public Discourse in the Age of Show Business", Penguin Group, New York 1986.

Ritzer G., "Magiczny świat konsumpcji”, transl. by L. Stawowy, Warszawskie Wydawnictwo Literackie Muza, Warsaw 2001.

Stachyra G., "Radio Charitainment. A Case Study of Radio Eska's Campaign 'We Undress to Dress", in: "Radio: Community, Challanges, Aesthetics", ibid. (ed.), Wydawnictwo Uniwersytetu Marii Curie-Skłodowskiej, Lublin 2013, pp. 287-297.

Sternicka M., "Cyberprzestrzeń jako dostawca rozrywki oraz miejsce autokreacji - na przykładzie serwisu internetowego YouTube”, in: “'Małe tęsknoty?' Style życia w czasie wolnym we współczesnym społeczeństwie”, W. Muszyński (ed.), Wydawnictwo Adam Marszałek, Toruń 2009, pp. 84-95.

Szatan M., "Politainment, czyli jak media przekształcają politykę w spektakl (na przykładzie kampanii wyborczej 2011)”, in: “Rozrywka w mediach”, K. Burska, P. Czarnek (eds.), Wydawnictwo Primum Verbum, Lodz 2012, pp. 201-211.

\section{Paulina Czarnek-Wnuk}

\section{Hybrid forms of entertainment in the media}

\section{(Summary)}

The media environment is an extremely variable universe where every now and again we can observe the emergence of new phenomena. Many of those form through blending of often rather different and distant areas. As a result, there emerge hybrid forms, which are not entirely established or completely defined. This article is focussed on those kinds of mixed types based on media entertainment, e.g. infotainment, edutainment, politainment, politicotainment, docutainment etc., which can be observed in the means of mass communication. The goal of the study was to define their essence, their distinctive features, and to indicate the place of those hybrid forms within the media discourses being carried on today.

Keywords: media, entertainment, hybrid. 